\title{
MOLECULAR GENETICS OF NON-SYNDROMIC CLEFTS REVISITED
}

\author{
SAIKRISHNA L. ${ }^{1}$, BHASKAR L.V.K.S. ${ }^{2}$, RAJASEKHAR M. ${ }^{*}$ \\ 1Department of Zoology, Sri Venkateswara University, Tirupati, India \\ 2Department of Biomedical Sciences, Sri Ramachandra University, Chennai, India \\ *Corresponding Author: Email- drmrsekhar@rediffmail.com
}

Received: October 22, 2010; Accepted: January 27, 2011

\begin{abstract}
Cleft of the lip and palate $(C L / P)$ are generally divided in to two groups, isolated cleft palate and cleft with or without cleft palate representing a heterogeneous group of disorders affecting the upper lip and the roof the mouth. Non-syndromic cleft lip and palate incidence is 1 in 700 to 1000 live babies with ethnic and geographic variations. Various independent association and linkage studies using different populations have identified several loci. Numerous genes have been reported in studies demonstration associations and/or linkage of the cleft lip and palate phenotypes to alleles of microsatellite markers and single nucleotide polymorphisms within specific genes that regulate transcription factor, growth factor, cell signalling and detoxification metabolisms. Currently, efforts are focussed to identify the genes and genetic variations within the numerous candidate genes that have been found to associate with the expression of the orofacial cleft phenotype. In conclusion, the genetic basis of CL/P is still contentious because of genetic complexity of clefting.
\end{abstract}

Key words: Cleft lip, palate, genetics, gene, SNP

Introduction: Cleft lip, with or without cleft palate, is a most challenging congenital malformation with variable phenotype. In general, facial clefting results when medial, lateral, and maxillary nasal processes on either left, right or both sides of the forming craniofacial complex do not fuse completely. Babies may have both cleft lip and palate, or either on its own. Prevalence varies by ethnic group, geographic region and sex. Cleft lip and palate is more common in boys and cleft palate alone in girls. North American Indians and Asians have the highest prevalence rates (1/500), while Caucasians have intermediate rates (1/1000) and Africans have the lowest prevalence rates $(1 / 2500)$. Influence of seasonal variations on the incidence of cleft lip and palate was also reported [1]. Broadly speaking, approximately $30 \%$ of CL/P cases are syndromic and are associated with some recognizable anomalies, but $70 \%$ are of nonsyndromic and occur as isolated condition [2,3]. More than 400 syndromes have been already associated with CL/P [4]. The study of congenital cleft lip and cleft palate anomalies has been the subject of debate regarding the etiology and mode of transmission [5]. The etiological factors include heredity, consanguinity, maternal environment, demographic factors and other factors like intrauterine posture, drugs, vitamins, alcohol consumption, smoking, infections, diet etc [6]. The patients with cleft lip and palate present complex biologic, sociologic and psychologic problems and their rehabilitation involves several disciplines. Both genetic and environmental influences are believed to cause cleft lip and palate. Dermotoglyphic features, dental anomalies and handedness are the well studied sub-phenotypes for the nonsyndromic cleft lip and palate. A retrospective study from Canada has revealed that there were a significantly larger number of left-sided clefts in the sample than right-sided clefts. The proportion of left-sided clefts among left-handers was higher than that among right-handers. Furthermore, non-right-handed patients show a greater tendency for having a cleft than the right-handed patients, but the specific nature of this relationship remains unclear [7]. The correlation between dermatoglyphic patterns and nonsyndromic cleft lip and palate has been extensively studied $[8,9,10,11]$. In patients with OFCs several dental traits such as hypodontia, supernumerary teeth, dental asymmetry and delay in tooth development on the side of cleft was reported [12].

Gene identification for nonsyndromic cleft lip and palate is difficult because of varying levels of its penetrance, sex differences and other environmental factors [13]. Numerous environmental risk factors have been shown in several epidemiologic studies to be strongly associated with increased prevalence of orofacial clefts. Till now, no susceptibility gene for OFC has 
been detected consistently, though a large number of genes have been speculated to be associated with the OFC. Furthermore, the complex nature of the nonsyndromic clefts are attributed to the multiple interacting genes conferring moderate effects have been proposed to provide susceptibility to OFCs $[14,15,16]$. However, the genetic component of cleft that causes the susceptibility to respond to the environment is still not clearly evident.

\section{Insights from syndromic clefts}

Cleft lip or palate can be seen as an associated feature in approximately 300 syndromes. Studies on these syndromes had given sufficient clues to identify the genes that cause the non syndromic clefts [17]. Van derWoude syndrome (VWS) (OMIM 119300 ) is the most common autosomal dominant disorder which is always associated with CL/P [18]. Interferon regulatory factor 6 (IRF6) which is located in the chromosome 1 is the major gene that is associated with WWS, $[19,20]$ and, later its variants were found to be significantly associated with nonsyndromic clefts [21,22]. The Wolf-Hirschhorn syndrome (WHS) (OMIM 194190), which is caused by the partial deletion of the short arm of Chromosome $4(4 p)$, is also characterized by oral clefts [23]. Fluorescence in situ hybridization (FISH) analysis of eight Finnish WHS patients revealed that five patients are not having one copy of MSX1 and the other in three where one individual possessing cleft palate has shown the presence of two hybridization signals [24]. Analysis of Dutch family with $\mathrm{CL} / \mathrm{P}, \mathrm{CP}$ and selective tooth agenesis revealed a heterozygous nonsense mutation in MSX1 gene. Furthermore, complete sequencing of the MSX1 gene in 1000 unrelated CL/P individuals showed that mutations in MSX1 alone could account for $2 \%$ of isolated CL/P [25]. Kallmann syndrome (KAL2) (OMIM147950) is also inherited in an autosomal dominant fashion with orofacial cleft in $5-10 \%$ of the cases. Approximately $20 \%$ of Kallmann syndrome cases a loss-of-function mutation in FGFR1 has been reported [26]. Recent analysis has shown 3 to $5 \%$ of nonsyndromic cleft lip or palate is also caused by functional impairment in the FGFR1, FGFR2, FGFR3, and FGF8 genes [27]. Cleft lip/palate ectodermal dysplasia syndrome (CLPED) is an autosomal recessive disorder is also characterised by cleft lip with or without cleft palate. Positional cloning experiments identified mutations of the poliovirus receptor like-1 gene (PVRL1) in CLPED families of Margarita Island, Israel, and Brazil [28]. Investigation of the W185X nonsense mutation of PVRL1 revealed its association with clefting in Northern Venezuela [29]. Whereas the same was not found in any of the nonsyndromic cleft populations of Italian origin [30] and Taiwanese [31].
A common glycine allele of the G361V polymorphism was significantly associated with orofacial clefting phenotypes in all lowan, Danish, and Filipino families [32]. The ectrodactylyectodermal dysplasia-cleft syndrome (EEC, MIM 129900 ) is a rare form of ectodermal dysplasia, an autosomal dominant disorder has given the hints to identify the genes such as TP63 (OMIM 603273; 3q27) [33]. Analysis of a large family with 10 affected persons revealed maximal linkage between EEC and chromosome 3q27, which contains a known EEC gene - tumor protein 63 (TP63) [34]. Analysis of 16 exons of TP63 gene in 100 Thai nonsyndromic $\mathrm{CL} / \mathrm{P}$ patients suggesting a causative role of TP63 gene variants in non-syndromic CL/P [35]. Cleft palate with ankyloglossia (CPX; MIM 303400) is inherited as a semi-dominant X-linked disorder previously described in several large families of different ethnic origins and has been the subject of several studies that localized the causative gene to Xq21. Positional cloning identified the CPX locus as the gene encoding T-BOX 22 (TBX22) [36]. TBX22 is a member of the T-box containing transcription factor gene family that is conserved throughout metazoan evolution. Analysis of Thai non-syndromic CP cases for TBX22 mutations confirming its importance as a frequent cause of non-syndromic CP across different populations [37]. Opitz syndrome is characterized by midline abnormalities such as hypertelorism, cleft palate, and hypospadias. Opitz syndrome is heterogeneous with an X-linked recessive form caused by mutations in the MID1 gene that located at Xp22.3 [38]. MID1 encodes a member of the Bbox family of proteins, which contain protein-protein interaction domains, including a RING finger, and is implicated in fundamental processes like body axis patterning and regulation of cellular proliferation. A Non-random tranmission that observed in MID1 haplotypes in male NSCLP patients suggests that MID1 may play a role in NSCLP [39]. Lymphedemadistichiasis is an autosomal dominant disorder that classically presenting with lymphedema at puberty and distichiasis at birth and some other complications such as cardiac defects, varicose veins, ptosis, cleft palate, spinal extradural cysts, and photophobia $[40,41])$. This condition has been decisively linked to mutations in the forkhead transcription factor FOXC2 which have been primarily frameshift mutations truncating the protein $[40,41]$. Bamforth-Lazarus syndrome (BLS) is a rare syndrome characterized mainly by congenital hypothyroidism, bilateral choanal atresia, cleft palate, bifid epiglottis, and spiky or curly hair. Mutations in the FOXE1 (9q22) gene have been associated with Bamforth Lazarus syndrome [42]. Analysis of candidate genes within 9q22-q33 revealed that the FOXE1 is a major gene for cleft lip with or without cleft palate [43]. 


\section{Animal models}

From the beginning of twentieth century, the mouse has developed into a foremost mammalian model system for genetic research. Scientists from diverse fields have gravitated to the mouse because of its close genetic and physiological similarities to humans, as well as the ease with which its genome can be manipulated and analyzed [44]. Furthermore, the development of the embryonic face is similar in mice and humans [45]. The development of the upper lip has been wellreviewed and presented for use of the CL/P mutants recently [46]. Several genetically altered mouse models such as knockout, knock-in, gene-trapped, spontaneous mutations and chemically induced mutations provided an excellent opportunity to study $\mathrm{CL} / \mathrm{P}$. Many CL/P mouse models have counterparts in syndromic CL/P forms found in humans. Selection of an appropriate genetic model describing the genetic makeup of an underlying phenotype of interest is an intrinsic part of the gene mapping. Animal models with clefts arising spontaneously or as a result of mutagenesis experiments serve as best models for gene mapping studies of cleft lip with or without cleft palate [47]. In mice, for $C L / P$, there are 10 spontaneous or induced Mendelian mutants, 2 conditional (tissue specific) knockout mutants, 1 new multifactorial model based on a compound mutant and 1 multifactorial genetic model represented by several related strains, Previous studies on mouse CL/P mutants and human population data clearly indicating that the genes and signaling pathways that cause $\mathrm{CL} / \mathrm{P}$ are different from those that cause CP [48]. In fact, studies in these animal models have helped to identify several genes essential for palatal formation.

The Msx1 homeobox gene is expressed at diverse sites including facial primordial, and is required for expression of Bmp2 and Bmp4 in the palatal mesenchyme and Shh in the medial edge epithelia and play a major role in signalling processes between tissue layers [49]. For Msx1, two independent knockouts that results in 100\% cleft palate [50,51]. Mice lacking Msx1 function manifest a cleft secondary palate, a deficiency of alveolar mandible and maxilla and a failure of tooth development $[49,52]$. MSX1 is deleted in cases of the human $4 p$-syndrome, which usually includes clefts. The Tgfß family represents a class of signaling molecules that play a major role in development of the orofacial region and its isoforms 1, 2 and 3 are expressed during this process and mediated through the Smad signalling system [53]. Mice lacking TGF-beta 3 exhibits an incompletely penetrant failure of the palatal shelves to fuse and leading to orofacial developmental abnormalities perticularly cleft palate $[54,55]$. Endothelin-1 (EDN1) is synthesized by the vascular endothelial cells and is found in plasma. Active endothelin peptides are produced from an inactive transitional form in a step that catalyzed by endothelin-converting enzyme (ECE). Mice lacking EDN1 have shown several craniofacial abnormalities, including cleft palate [56]. The mouse deficient in ECA or in endothelin-A receptor genes also has shown almost identical abnormalities to those of EDN1-deficient mice [57]. In zebra fish, Endothelin-1 is expressed ventrally in the primordia of the pharyngeal arches and helps in patterning of pharyngeal cartilage. Kimmel et al [58] have demonstrated the role of EDN1 in the sizing of pharyngeal skeletal elements of the jaw and opercular regions in zebra fish upon injection of a morpholino. But genes involved in the endothelin pathway (EDN1, ECE1, EDNRA, EDNRB) have not shown significant linkage with orofacial clefts [59]. In the mammalian central nervous system the chief inhibitory neurotransmitter is gamma-aminobutyric acid $(G A B A)$. Mice homozygous for loss of function mutation in the GABA synthesizing enzyme glutamate decarboxylase 1 (GAD67) causes cleft palate, indicate role of GABA in the palate development $[60,61]$.

\section{Linkage studies}

Linkage studies screen the whole genome and use parametric or nonparametric methods such as allele sharing methods with no assumptions on the mode of inheritance, penetrance or disease allele frequency. The underlying principle of linkage studies is the cosegregation of a gene marker and disease phenotype within a family, to determine if the marker and the disease gene are physically linked. Large-scale family linkage analysis has provided a statistical method of detecting the chromosomal location of possible loci within a population where gene defects might result in a predisposition to CL/P.

The first linkage analysis suggested possible linkage between CL/P and the blood clotting factor XIII gene (F13A) on chromosome 6p [62]. Unfortunately, further evidence for support of the $F 13 A$ gene has been more equivocal $[63,64]$. Suggestive linkage of chromosome $4 q$ and CL/P was shown in one family [65] and is supported by the evidence of association to the same region [66], but a later study showed evidence against linkage in this region [67]. However, successive linkage studies have revealed at least 20 contributing chromosomal regions [68].

A possible interaction between $6 p 23$ and $2 p 13$ chromosomal regions was reported in $38 \mathrm{CL} / \mathrm{P}$ multiplex families from Italy [69]. Regions on Chromosomes $6 p, 2 p, 4 q$ and $17 q$ have all shown some evidence of linkage to CL/P [70]. However, no evidence of linkage to selected candidate genes on Chromosomes 2, 4, 6 or 19 in Swedish multiplex CL/P families was observed [71]. Similarly, 36 CL/P multiplex Chinese families did not show significant linkage to any of these regions [72]. segregation 
analyses using 11 multigenerational families with $\mathrm{CL} / \mathrm{P}$ found significant linkage with $\mathrm{BCL} 3$, a protooncogene on Chromosome 19q [73]. Subsequent studies failed to find further evidence of linkage to this marker, but they did find a significant association for an allele at this marker using the transmission disequilibrium test (TDT) [74,75]. Support for linkage to different chromosome 1 regions (1q21 and 1q32-42.3) and CL/P was reported with the positive scores for the $1 \mathrm{p} 36$ region near the MTHFR locus [76]. Significant linkage disequilibrium between the GABRB3 gene and CL/P was reported [77].

\section{Genome-wide screens}

Genome-wide scan that conducted using $10-\mathrm{cM}$ and 5-cM mapping panels in 92 UK sib pairs of $\mathrm{CL} / \mathrm{P}$ revealed seven loci of which $2 p 13$ (TGFA) and 6p23-24 were reported earlier [78]. Analysis of Chinese multiplex families revealed most significant linkage at $3 q 26$ and $4 q 21[72]$. Genome-wide scan of two large Syrian families detected 17p13.1 chromosomal region [79]. 10 multiplex families of Mexico, Argentina, and the United States showed intriguing evidence of linkage to $2 q$ [80]. $38 \mathrm{CL} / \mathrm{P}$ multiplex families of West Bengal revealed statistically significant two-point linkage results with markers on Chromosome 5, 7, 15 and 20 [81]. 18 consanguineous Turkish CL/P families yielded statistically significant regions on Chromosomes 4, 10,12 , and 15 [82]. A meta-analysis of 13 genome scans (10-cM) of 388 extended multiplex families with $\mathrm{CL} / \mathrm{P}$ from seven diverse populations has pinpointed highly significant loci with a maximum heterogeneity LOD score 6.6 near $9 q 21$ and another (2q32-35) [83]. Analysis of two Indian pedigrees yielded 11 genomic regions with most significant evidence of linkage on chromosome 13q33.1-34 [84].

Genome wide linkage analysis was performed on an extended American family (UR410) of selfreported European origin with NSCL/P and likely autosomal dominant mode of inheritance has shown the evidence of linkage for marker rs728683 on Chromosome 18q21.1 [85]. Genome-wide scan using the array-CGH also helped in identifying submicroscopic deletions/duplications simultaneously onto the genome sequence. The use of multiple probes simultaneously is now possible using $105 \mathrm{~K}$ oligonucleotide probes, spaced at $30 \mathrm{~K}$ through the genome. Array comparative genomic hybridization provides information on the genomic imbalances, including minor deletions and duplications that cannot be detected by conventional cytogenetic methods. Several novel candidate genes associated with cleft lip and palate were identified using arrayCGH $[86,87]$.

\section{Association studies}

A large number of putative genes chosen on the basis of biochemical and pharmacological evidence and candidate sites identified using genome scans and linkage studies have been tested for association with CL/P. Genetic association studies intend to test whether single-locus genotype or minor alleles frequencies are different between disease phenotype and healthy controls. A specific allele has to be suspected as susceptible or protective and therefore tested in either a casecontrol study or a family-based association design. Several case-control association studies that conducted independently have provided evidence that variants in the genes MTHFR, ARNT, TGFA, GAD1, MSX1, RARA, TGFB3 are associated with the CL/P phenotype. Association studies provide a powerful tool for identifying disease susceptibility genes of minor importance. In this regard, using the case-control design, Tolarova et al. [88] first observed that homozygotes for the $677 \mathrm{~T}$ allele were three times more frequent in CL/P Argentinean patients than in controls. However, these findings were not confirmed by most of the subsequent studies using California [89], Brazil [90], Polish [91] and Irish [92] population samples. However, in an, homozygosity for the C677T allele was associated with an increased risk for isolated cleft palate (OR $=3.2$; 95 percent $\mathrm{Cl}: 1.3,7.9$ ) and possibly for cleft lip with or without cleft palate $(O R=1.6$; 95 percent $\mathrm{Cl}: 0.8,3.4)$ [92]. An increased risk due to the maternal MTHFR genotype (677 T or 1282A alleles) on predisposition to CL/P was suggested by several studies $[14,93,94,95,96]$. In a recent study from china reports moderate association between the 677C-T polymorphism and non_syndromic cleft lip/palate in families from northern China but not in those from southern China suggesting the genetic heterogeneity [97]. In case and control studies false associations may also occur due to population stratification [98]. Because of this, family-based association designs have become increasingly popular. Recent technological advances made it feasible to perform high-throughput sequencing of candidate genes in large patient cohorts to know the genes involved in pathways that regulate transcription factors, growth factors, cell signalling and detoxification metabolisms, but we still have important work to do in the field of NSCLP.

\section{Environmental factors causing cleft}

Although genes definitely play a role in the development of this defect, environmental factors, including maternal smoking, stress, heavy alcohol intake, infections, folic acid deficiency, and Vitamin A intoxication are suspected $[99,100,101]$. Several studies have revealed that high doses of corticosteroids cause cleft palate in rodents and rabbits $[101,102,103]$. Stressful life events appear to increase the maternal corticotrophin-releasing 
hormone and corticosteroid during pregnancy $[104,105]$, and increased risk of clefts among infants born to those mothers $[102,106]$. Furthermore, usage of corticosteroid medications during the first trimester of pregnancy increased risk of oral clefts $[107,108]$.

Smoking is practised by about a third of the world's population aged 15 years or older, including some $12 \%$ of women [109]. Cigarette smoking during pregnancy was associated with cleft defects $[6,99,110]$. In contrast, some studies found no association with maternal smoking for any form oral clefts [111,112]. Meta-analysis of 24 case-control and cohort studies revealed significant association with an overall odds ratio of $1.34(95 \% \mathrm{Cl}=1.25$ 1.44) [113]. When maternal smoking is considered along with certain genotypes the effect was more significant. The maternal glutathione s-transferase Ө-1 (GSTT1) genotype [114] or infant MSX1 genotypes [115] combined with maternal smoking significantly increased the risk of $\mathrm{CL} / \mathrm{P}$.

The possible association between maternal alcohol use during pregnancy and risk of oral clefts in the offspring have been contradictory. Earlier studies demonstrated that the alcohol consumption during pregnancy is associated with orofacial clefts [111,116]. Maternal alcohol consumption during the first trimester of pregnancy increased risk for isolated CP, but not for CLP [117]. Another study, found that maternal alcohol use during pregnancy among oral cleft cases was slightly more frequent than among controls [118]. A recent populationbased case-control study demonstrated that even a low level of alcohol consumption during pregnancy was significantly elevated the risk of orofacial clefts in the offspring [119].

Vitamins of B complex including folic acid supplementation during pregnancy have been shown to be effective in preventing cleft lip and palate in humans [120]. Folic acid supplementation ( $0.4 \mathrm{mg} / \mathrm{day})$ has been recommended by the US Public Health Service for all women of child bearing age to reduce the likelihood of birth defects [121]. Epidemiologic studies have proved that the consumption $4 \mathrm{mg}$ of folic acid/day is associated with a reduced risk of many birth defects [122].

\section{Cleft lip and palate research in India}

A large number of studies for NSCLP have been conducted mainly in the Caucasoid population. However, it is desirable to perform similar studies in different ethnic groups to reiterate the status of the association or linkage identified. Indian population is very well suited for such studies as it satisfies many criteria required for the investigation of complex traits. Besides, Indian population is an attractive large reservoir of samples both due to its population size as well as the high rate of marital stability, the latter essential for family based analysis. Work on genetics of NSCLP has been initiated since the last
5-6 years by several groups. Initial studies on genetics of cleft lip and palate was by conducted by foreign researchers. Genome-wide scan on $38 \mathrm{CL} / \mathrm{P}$ multiplex families of West Bengal revealed statistically significant two-point linkage results with markers on Chromosome $7 \quad(\mathrm{LOD}=1.89)$, Chromosome $5(\mathrm{LOD}=1.76)$, Chromosome 15 $(\mathrm{LOD}=1.55)$, and Chromosome $20(\mathrm{LOD}=1.46)$ [81]. Analysis of two Indian pedigrees identified 11 genomic regions that could potentially harbour CL/P susceptibility variations with most significant evidence of linkage for Chromosome 13q33.1-34 at marker rs 1830756 with heterogeneity LOD score of 5.57 [84]. A total of 323 NSCLP patients, 116 of their mothers, 108 of their fathers, and 214 normal controls that examined for IRF6 G820A, MTHFR C677T, and MTHFR A1298C revealed combined genotypes IRF6 GG/MTHFR 677CT together form greater risk for NSCLP [123]. Presently, the author's group is carrying out SNP genotyping of four candidate genes involved in the detoxification pathway.

\section{Future strategies}

Non-syndromic CL/P is a polygenic, multi-factorial disorder, showing complex inheritance and so multiple genes in combination with lifestyle and environmental factors contribute to its aetiology. Considering the complex nature of NSCLP, with no clue to the number and nature of genes involved or their location, it is difficult to search for the genes using the conventional techniques that help unravel the genes for single gene disorders. The challenge is now to fine map the putative regions and identify genes in which variants are more likely to increase the risk for NSCLP. Therefore, it is anticipated that there are additional genes involved in NSCLP that are yet to be identified, and the functional effects of identified mutations have yet to be discerned. Furthermore, the gene environment interaction will become more evident from the studies that include maternal and foetal genotypes along with gestational environmental exposures. The technological advancements in high-throughput genotyping and powerful statistical methods have accelerated the discovery of loci conferring susceptibility for complex diseases through the use of genome wide scans. Non-parametric method of linkage analysis using large collection of affected sib-pairs along with the genome scan studies using affected sib-pairs would be a more effective and favoured strategy to track genes of minor effect. Haplotype analysis could be informative where genotypic combination might be crucial in providing the susceptibility. More number of samples and families will be needed to unravel the genes of minor effect and to establish the interaction of these genes with other genes and with the environment. Considering NSCLP is a polygenic disorder, genegene interaction among putative markers is 
expected to yield important clues to the underlying pathology.

\section{References}

[1] Adler S. (1969) Journal of Communication Disorders, 2, 328-335.

[2] Schutte B.C., Murray J.C. (1999) Hum Mol Genet, 8, 1853-1859.

[3] Wang X. (2004) Zhonghua Kou Qiang Yi Xue Za Zhi, 39, 362-364.

[4] Papadopulos N.A., Zeilhofer H.F., Papadopoulos M.A., Feussner H., Henke J., Kovacs L., Horch H.H., Biemer E. (2003) Mund Kiefer Gesichtschir, 7, 70-75.

[5] Balgir R.S. (1986) J Indian Med Assoc, 84, 369372.

[6] Chung K.C., Kowalski C.P., Kim H.M., Buchman S.R. (2000) Plast Reconstr Surg, 105 485-491.

[7] Daskalogiannakis J., Kuntz K.L., Chudley A.E., Ross R.B. (1998) Cleft Palate Craniofac J, 35, 46-51.

[8] Deshmukh R.N., Grewal M.S., Sidhu S.S. (1981) Indian J Med Res, 73, 584-589.

[9] Kanematsu N., Yoshida Y., Kishi N., Kawata K., Kaku M., Maeda K., Taoka M., Tsutsui H. (1986) J Maxillofac Surg, 14, 74-82.

[10] Kobyliansky E., Bejerano M., Yakovenko K., Katznelson M.B. (1999) Coll Antropol, 23, 1-51.

[11] Scott N.M., Weinberg S.M., Neiswanger K., Daack-Hirsch S., O'Brien S., Murray J.C., Marazita M.L. (2005) Cleft Palate Craniofac J, 42, 362-366.

[12] Eerens K., Vlietinck R., Heidbuchel K., Van Olmen A., Derom C., Willems G., Carels C. (2001) Cleft Palate Craniofac J, 38, 374-378.

[13] Murray J.C. (1995) Am J Hum Genet, 57, 227232.

[14] Gaspar D.A., Matioli S.R., de Cassia Pavanello R., Araujo B.C., Alonso N., Wyszynski D., Passos-Bueno M.R. (2004) Eur J Hum Genet, 12, 521-526.

[15] Lammer E.J., Shaw G.M., Iovannisci D.M., Finnell R.H. (2005) Epidemiology, 16, 698-701.

[16] Shaw G.M., lovannisci D.M., Yang W., Finnell R.H., Carmichael S.L., Cheng S., Lammer E.J. (2005) Am J Epidemiol, 162, 12071214.

[17] Stanier P., Moore G.E. (2004) Hum Mol Genet, 13 Spec No 1, R73-81.

[18] Van Der Woude A. (1954) Am J Hum Genet, 6 , 244-256.

[19] Schutte B.C., Bjork B.C., Coppage K.B., Malik M.I., Gregory S.G., Scott D.J., Brentzell L.M., Watanabe Y., Dixon M.J., Murray J.C. (2000) Genome Res, 10, 81-94.
[20] Kondo S., Schutte B.C., Richardson R.J., Bjork B.C., Knight A.S., Watanabe Y., Howard E., de Lima R.L., Daack-Hirsch S., Sander A., McDonald-McGinn D.M., Zackai E.H., Lammer E.J., Aylsworth A.S., Ardinger H.H., Lidral A.C., Pober B.R., Moreno L., Arcos-Burgos M., Valencia C., Houdayer C., Bahuau M., Moretti-Ferreira D., Richieri-Costa A., Dixon M.J., Murray J.C. (2002) Nat Genet, 32, 285-289.

[21] Zucchero T.M., Cooper M.E., Maher B.S., Daack-Hirsch S., Nepomuceno B., Ribeiro L., Caprau D., Christensen K., Suzuki Y., Machida J., Natsume N., Yoshiura K., Vieira A.R., Orioli I.M., Castilla E.E., Moreno L., Arcos-Burgos M., Lidral A.C., Field L.L., Liu Y.E., Ray A., Goldstein T.H., Schultz R.E., Shi M., Johnson M.K., Kondo S., Schutte B.C., Marazita M.L., Murray J.C. (2004) N Engl J Med, 351, 769-780.

[22] Scapoli L., Palmieri A., Pezzetti F., Carinci F., Marchesini J., Martinelli M., Delaiti G. Tognon M., Carinci P., Gombos F. (2004) Am J Med Genet A, 127A, 211.

[23] Morishita M., Shiba R., Chiyo H., Furuyama J., Fujita H., Atsumi Y. (1983) J Oral Maxillofac Surg, 41, 601-605.

[24] Nieminen P., Kotilainen J., Aalto Y., Knuutila S., Pirinen S., Thesleff I. (2003) J Dent Res, 82, 1013-1017.

[25] Jezewski P.A., Vieira A.R., Nishimura C., Ludwig B., Johnson M., O'Brien S.E., Daack-Hirsch S., Schultz R.E., Weber A., Nepomucena B., Romitti P.A., Christensen K., Orioli I.M., Castilla E.E., Machida J., Natsume N., Murray J.C. (2003) J Med Genet, 40, 399-407.

[26] Dode C., Teixeira L., Levilliers J., Fouveaut C., Bouchard P., Kottler M.L., Lespinasse J., Lienhardt-Roussie A., Mathieu M., Moerman A., Morgan G., Murat A., Toublanc J.E., Wolczynski S., Delpech M., Petit C., Young J., Hardelin J.P. (2006) PLoS Genet, 2, e175.

[27] Riley B.M., Murray J.C. (2007) Am J Med Genet A, 143A, 3228-3234.

[28] Suzuki K., Hu D., Bustos T., Zlotogora J., Richieri-Costa A., Helms J.A., Spritz R.A. (2000) Nat Genet, 25, 427-430.

[29] Sozen M.A., Suzuki K., Tolarova M.M., Bustos T., Fernandez Iglesias J.E., Spritz R.A. (2001) Nat Genet, 29, 141-142.

[30] Scapoli L., Marchesini J., Martinelli M., Pezzetti F., Carinci F., Palmieri A., Rullo R., Gombos F., Tognon M., Carinci P. (2005) Am J Med Genet A, 132A, 302-304. 
[31] Tseng Y.T., Hsiao H.H., Hsiao H.P., Tsai W.C., Chiu H.H. (2006) Int J Oral Maxillofac Surg, 35, 453-455.

[32] Avila J.R., Jezewski P.A., Vieira A.R., Orioli I.M., Castilla E.E., Christensen K., DaackHirsch S., Romitti P.A., Murray J.C. (2006) Am J Med Genet A, 140, 25622570.

[33] van Bokhoven H., Brunner H.G. (2002) Am J Hum Genet, 71, 1-13.

[34] Ray A.K., Marazita M.L., Pathak R., Beever C.L., Cooper M.E., Goldstein T., Shaw D.F., Field L.L. (2004) Clin Genet, 66, 217-222.

[35] Leoyklang P., Siriwan P., Shotelersuk V. (2006) J Med Genet, 43, e28.

[36] Braybrook C., Doudney K., Marcano A.C., Arnason A., Bjornsson A., Patton M.A., Goodfellow P.J., Moore G.E., Stanier P. (2001) Nat Genet, 29, 179-183.

[37] Suphapeetiporn K., Tongkobpetch S., Siriwan P., Shotelersuk V. (2007) Clin Genet, 72, 478-483.

[38] Quaderi N.A., Schweiger S., Gaudenz K., Franco B., Rugarli E.I., Berger W., Feldman G.J., Volta M., Andolfi G., Gilgenkrantz S., Marion R.W., Hennekam R.C., Opitz J.M., Muenke M., Ropers H.H., Ballabio A. (1997) Nat Genet, 17, 285-291.

[39] Scapoli L., Martinelli M., Arlotti M., Palmieri A., Masiero E., Pezzetti F., Carinci F. (2008) Eur J Oral Sci, 116, 507-511.

[40] Fang J., Dagenais S.L., Erickson R.P., Arlt M.F., Glynn M.W., Gorski J.L., Seaver L.H., Glover T.W. (2000) Am J Hum Genet, 67, 1382-1388.

[41] Bahuau M., Houdayer C., Tredano M., Soupre V., Couderc R., Vazquez M.P. (2002) Clin Genet, 62, 470-473.

[42] Castanet M., Park S.M., Smith A., Bost M., Leger J., Lyonnet S., Pelet A., Czernichow P., Chatterjee K., Polak M. (2002) Hum Mol Genet, 11, 2051-2059.

[43] Moreno L.M., Mansilla M.A., Bullard S.A., Cooper M.E., Busch T.D., Machida J., Johnson M.K., Brauer D., Krahn K., Daack-Hirsch S., L'Heureux J., ValenciaRamirez C., Rivera D., Lopez A.M., Moreno M.A., Hing A., Lammer E.J., Jones M., Christensen K., Lie R.T., Jugessur A., Wilcox A.J., Chines P., Pugh E., Doheny K., Arcos-Burgos M., Marazita M.L., Murray J.C., Lidral A.C. (2009) Hum Mol Genet, 18, 4879-4896.

[44] Thyagarajan T., Totey S., Danton M.J., Kulkarni A.B. (2003) Crit Rev Oral Biol Med, 14, 154-174.

[45] Diewert V.M., Wang K.Y. (1992) Crit Rev Oral Biol Med, 4, 111-130.
[46] Jiang R., Bush J.O., Lidral A.C. (2006) Dev Dyn, 235, 1152-1166.

[47] Herron B.J., Lu W., Rao C., Liu S., Peters H., Bronson R.T., Justice M.J., McDonald J.D., Beier D.R. (2002) Nat Genet, 30, 185-189.

[48] Gritli-Linde A. (2007) Dev Biol, 301, 309-326.

[49] Zhang Z., Song Y., Zhao X., Zhang X., Fermin C., Chen Y. (2002) Development, 129, 4135-4146.

[50] Satokata I., Maas R. (1994) Nat Genet, 6, 348356.

[51] Houzelstein D., Cohen A., Buckingham M.E., Robert B. (1997) Mech Dev, 65, 123-133.

[52] Lu M.F., Cheng H.T., Lacy A.R., Kern M.J., Argao E.A., Potter S.S., Olson E.N., Martin J.F. (1999) Dev Biol, 205, 145-157.

[53] Greene R.M., Nugent P., Mukhopadhyay P., Warner D.R., Pisano M.M. (2003) J Cell Physiol, 197, 261-271.

[54] Proetzel G., Pawlowski S.A., Wiles M.V., Yin M., Boivin G.P., Howles P.N., Ding J., Ferguson M.W., Doetschman T. (1995) Nat Genet, 11, 409-414.

[55] Kaartinen V., Voncken J.W., Shuler C., Warburton D., Bu D., Heisterkamp N., Groffen J. (1995) Nat Genet, 11, 415-421.

[56] Kurihara Y., Kurihara H., Suzuki H., Kodama T., Maemura K., Nagai R., Oda H., Kuwaki T., Cao W.H., Kamada N., et al. (1994) Nature, 368, 703-710.

[57] Yanagisawa H., Yanagisawa M., Kapur R.P., Richardson J.A., Williams S.C., Clouthier D.E., de Wit D., Emoto N., Hammer R.E. (1998) Development, 125, 825-836.

[58] Kimmel C.B., Ullmann B., Walker M., Miller C.T., Crump J.G. (2003) Development, 130, 1339-1351.

[59] Pezzetti F., Scapoli L., Martinelli M., Carinci F., Brunelli G., Carls F.P., Palomba F., Gombos F., Carinci P., Tognon M. (2000) Ann Hum Genet, 64, 341-347.

[60] Condie B.G., Bain G., Gottlieb D.I., Capecchi M.R. (1997) Proc Natl Acad Sci U S A, 94, 11451-11455.

[61] Ding R., Tsunekawa N., Obata K. (2004) Neurotoxicol Teratol, 26, 587-592.

[62] Eiberg H., Bixler D., Nielsen L.S., Conneally P.M., Mohr J. (1987) Clin Genet, 32, 129132.

[63] Hecht J.T., Wang Y., Connor B., Blanton S.H., Daiger S.P. (1993) Am J Hum Genet, 52, 1230-1233.

[64] Vintiner G.M., Lo K.K., Holder S.E., Winter R.M., Malcolm S. (1993) J Med Genet, 30, 773-778.

[65] Beiraghi S., Foroud T., Diouhy S., Bixler D., Conneally P.M., Delozier-Blanchet D., Hodes M.E. (1994) Clin Genet, 46, 255256. 
[66] Mitchell L.E., Healey S.C., Chenevix-Trench G. (1995) Am J Hum Genet, 57, 1130-1136.

[67] Blanton S.H., Crowder E., Malcolm S., Winter R., Gasser D.L., Stal S., Mulliken J., Hecht J.T. (1996) Am J Hum Genet, 58, 239-241.

[68] Wyszynski D.F., Wu T. (2002) Cleft Palate Craniofac J, 39, 370-375.

[69] Pezzetti F., Scapoli L., Martinelli M., Carinci F., Bodo M., Carinci P., Tognon M. (1998) Genomics, 50, 299-305.

[70] Carinci F., Pezzetti F., Scapoli L., Martinelli M., Carinci P., Tognon M. (2000) Cleft Palate Craniofac J, 37, 33-40.

[71] Wong F.K., Hagberg C., Karsten A., Larson O., Gustavsson M., Huggare J., Larsson C., Teh B.T., Linder-Aronson S. (2000) Cleft Palate Craniofac J, 37, 357-362.

[72] Marazita M.L., Field L.L., Cooper M.E., Tobias R., Maher B.S., Peanchitlertkajorn S., Liu Y.E. (2002) Am J Hum Genet, 71, 349364.

[73] Stein J., Mulliken J.B., Stal S., Gasser D.L., Malcolm S., Winter R., Blanton S.H., Amos C., Seemanova E., Hecht J.T. (1995) Am J Hum Genet, 57, 257-272.

[74] Wyszynski D.F., Maestri N., Lewanda A.F., McIntosh I., Smith E.A., Garcia-Delgado C., Vinageras-Guarneros E., Wulfsberg E., Beaty T.H. (1997) Hum Hered, 47, 101-109.

[75] Martinelli M., Scapoli L., Pezzetti F., Carinci F., Carinci P., Baciliero U., Padula E. Tognon M. (1998) Genomics, 51, 177 181.

[76] Martinelli M., Scapoli L., Pezzetti F., Carinci F., Francioso F., Baciliero U., Padula E., Carinci P., Tognon M. (2001) Ann Hum Genet, 65, 465-471.

[77] Scapoli L., Martinelli M., Pezzetti F., Carinci F., Bodo M., Tognon M., Carinci P. (2002) Hum Genet, 110, 15-20.

[78] Prescott N.J., Lees M.M., Winter R.M., Malcolm S. (2000) Hum Genet, 106, 345-350.

[79] Wyszynski D.F., Albacha-Hejazi H., Aldirani M., Hammod M., Shkair H., Karam A., Alashkar J., Holmes T.N., Pugh E.W., Doheny K.F., McIntosh I., Beaty T.H., Bailey-Wilson J.E. (2003) Am J Med Genet A, 123A, 140-147.

[80] Zeiger J.S., Hetmanski J.B., Beaty T.H., VanderKolk C.A., Wyszynski D.F., BaileyWilson J.E., de Luna R.O., Perandones C., Tolarova M.M., Mosby T., Bennun R., Segovia M., Calda P., Pugh E.W., Doheny K., McIntosh I. (2003) Eur J Hum Genet, 11, 835-839.
[81] Field L.L., Ray A.K., Cooper M.E., Goldstein T., Shaw D.F., Marazita M.L. (2004) Am J Med Genet A, 130A, 265-271.

[82] Marazita M.L., Field L.L., Tuncbilek G., Cooper M.E., Goldstein T., Gursu K.G. (2004) Am J Med Genet A, 126A, 111-122.

[83] Marazita M.L., Murray J.C., Lidral A.C., ArcosBurgos M., Cooper M.E., Goldstein T., Maher B.S., Daack-Hirsch S., Schultz R., Mansilla M.A., Field L.L., Liu Y.E., Prescott N., Malcolm S., Winter R., Ray A., Moreno L., Valencia C., Neiswanger K., Wyszynski D.F., Bailey-Wilson J.E., Albacha-Hejazi H., Beaty T.H., Mclntosh I., Hetmanski J.B., Tuncbilek G., Edwards M., Harkin L., Scott R., Roddick L.G. (2004) Am J Hum Genet, 75, 161-173.

[84] Radhakrishna U., Ratnamala U., Gaines M., Beiraghi S., Hutchings D., Golla J., Husain S.A., Gambhir P.S., Sheth J.J., Sheth F.J., Chetan G.K., Naveed M., Solanki J.V., Patel U.C., Master D.C., Memon R., Antonarakis G.S., Antonarakis S.E., Nath S.K. (2006) Am J Hum Genet, 79, 580-585.

[85] Beiraghi S., Nath S.K., Gaines M., Mandhyan D.D., Hutchings D., Ratnamala U., McElreavey K., Bartoloni L., Antonarakis G.S., Antonarakis S.E., Radhakrishna U. (2007) Am J Hum Genet, 81, 180-188.

[86] Osoegawa K., Vessere G.M., Utami K.H., Mansilla M.A., Johnson M.K., Riley B.M., L'Heureux J., Pfundt R., Staaf J., van der Vliet W.A., Lidral A.C., Schoenmakers E.F., Borg A., Schutte B.C., Lammer E.J., Murray J.C., de Jong P.J. (2008) J Med Genet, 45, 81-86.

[87] Zhang W.G., Luo S.J., Zhu S.F., Tang S.M. (2008) Zhonghua Zheng Xing Wai Ke Za Zhi, 24, 123-125.

[88] Tolarova M.M., van Rooij I.A.L.M., Pastor M., van der Put N.M.J., Goldberg A., Hol F., Capozzi A., Thomas C.M.G., Pastor L., Mosby T., Ferrari C., Eskes T.K.A.B., Steegers-Theunissen R.P.M. (1998) Am J Hum Genet, 63:A27.

[89] Shaw G.M., Rozen R., Finnell R.H., Todoroff K., Lammer E.J. (1998) Am J Med Genet, 80, 196-198.

[90] Gaspar D.A., Pavanello R.C., Zatz M., PassosBueno M.R., Andre M., Steman S., Wyszynski D.F., Matiolli S.R. (1999) Am J Med Genet, 87, 197-199.

[91] Mostowska A., Hozyasz K.K., Jagodzinski P.P. (2006) Clin Genet, 69, 512-517.

[92] Mills J.L., Kirke P.N., Molloy A.M., Burke H., Conley M.R., Lee Y.J., Mayne P.D., Weir D.G., Scott J.M. (1999) Am J Med Genet, 86, 71-74. 
[93] Martinelli M., Scapoli L., Pezzetti F., Carinci F., Carinci P., Stabellini G., Bisceglia L., Gombos F., Tognon M. (2001) Am J Med Genet, 98, 357-360.

[94] Prescott N.J., Winter R.M., Malcolm S. (2002) J Med Genet, 39, 368-369.

[95] Jugessur A., Wilcox A.J., Lie R.T., Murray J.C., Taylor J.A., Ulvik A., Drevon C.A., Vindenes H.A., Abyholm F.E. (2003) Am J Epidemiol, 157, 1083-1091.

[96] van Rooij I.A., Vermeij-Keers C., Kluijtmans L.A., Ocke M.C., Zielhuis G.A., GoorhuisBrouwer S.M., van der Biezen J.J., Kuijpers-Jagtman A.M., SteegersTheunissen R.P. (2003) Am J Epidemiol, 157, 583-591.

[97] Zhu J., Ren A., Hao L., Pei L., Liu J., Zhu H., Li S., Finnell R.H., Li Z. (2006) Am J Med Genet A, 140, 551-557.

[98] Cardon L.R., Palmer L.J. (2003) Lancet, 361, 598-604.

[99] Ericson A., Kallen B., Westerholm P. (1979) Am J Obstet Gynecol, 135, 348-351.

[100] Lieff S., Olshan A.F., Werler M., Strauss R.P., Smith J., Mitchell A. (1999) Am J Epidemiol, 150, 683-694.

[101] Shaw G.M., Lammer E.J. (1999) J Pediatr, 134, 298-303.

[102] Fraser F.C., Warburton D. (1964) Plast Reconstr Surg, 33, 395-399.

[103] Walker B.E. (1971) Teratology, 4, 39-42.

[104] Marazita M.L., Jaskoll T., Melnick M. (1988) J Craniofac Genet Dev Biol, 8, 47-51.

[105] Fawcett L.B., Buck S.J., Beckman D.A., Brent R.L. (1996) Pediatr Res, 39, 856-861.

[106] Walker B.E. (1967) Proc Soc Exp Biol Med, $125,1281-1284$.

[107] Carmichael S.L., Shaw G.M. (1999) Am J Med Genet, 86, 242-244.

[108] Rodriguez-Pinilla E., Martinez-Frias M.L. (1998) Teratology, 58, 2-5.

[109] Evans D.R., Newcombe R.G., Campbell H. (1979) Br Med J, 2, 171-173.

[110] Khoury M.J., Weinstein A., Panny S., Holtzman N.A., Lindsay P.K., Farrel K., Eisenberg M. (1987) Am J Public Health, 77, 623-625.

[111] Romitti P.A., Lidral A.C., Munger R.G., DaackHirsch S., Burns T.L., Murray J.C. (1999) Teratology, 59, 39-50.

[112] Malloy M.H., Kleinman J.C., Bakewell J.M., Schramm W.F., Land G.H. (1989) Am J Public Health, 79, 1243-1246.

[113] Little J., Cardy A., Munger R.G. (2004) Bull World Health Organ, 82, 213-218.

[114] van Rooij I.A., Wegerif M.J., Roelofs H.M., Peters W.H., Kuijpers-Jagtman A.M., Zielhuis G.A., Merkus H.M., SteegersTheunissen R.P. (2001) Epidemiology, 12, 502-507.
[115] Beaty T.H., Hetmanski J.B., Zeiger J.S., Fan Y.T., Liang K.Y., VanderKolk C.A., Mclntosh I. (2002) Genet Epidemiol, 22, 1-11.

[116] Munger R.G., Romitti P.A., Daack-Hirsch S., Burns T.L., Murray J.C., Hanson J. (1996) Teratology, 54, 27-33.

[117] Lorente C., Cordier S., Goujard J., Ayme S., Bianchi F., Calzolari E., De Walle H.E., Knill-Jones R. (2000) Am J Public Health, 90, 415-419.

[118] Spilson S.V., Kim H.J., Chung K.C. (2001) Ann Plast Surg, 47, 477-481.

[119] DeRoo L.A., Wilcox A.J., Drevon C.A., Lie R.T. (2008) Am J Epidemiol, 168, 638646.

[120] Schubert J., Schmidt R., Syska E. (2002) Int J Oral Maxillofac Surg, 31, 410-413.

[121] Werler M.M., Louik C., Mitchell A.A. (1999) Am J Public Health, 89, 1637-1640.

[122] Wilcox A.J., Lie R.T., Solvoll K., Taylor J., McConnaughey D.R., Abyholm F., Vindenes H., Vollset S.E., Drevon C.A. (2007) BMJ, 334, 464.

[123] Ali A., Singh S.K., Raman R. (2009) Genet Test Mol Biomarkers, 13, 355-360.

[124] Wan W.D., Yang S.L., Liu J.Y., Cui Y.G., Zhou X.P., Guo F.F., Cheng H.Y., Cheng L., Xiao P.F., Lu Z.H. (2009) Beijing Da Xue Xue Bao, 41, 409-413.

[125] Sozen M.A., Hecht J.T., Spritz R.A. (2009) Genet Test Mol Biomarkers, 13, 617-621.

[126] Rinne T., Bolat E., Meijer R., Scheffer H., van Bokhoven H. (2009) Am J Med Genet A, 149A, 1948-1951.

[127] Matzuk M.M., Kumar T.R., Vassalli A., Bickenbach J.R., Roop D.R., Jaenisch R., Bradley A. (1995) Nature, 374, 354-356.

[128] Koo S.H., Cunningham M.C., Arabshahi B., Gruss J.S., Grant J.H., 3rd. (2001) Plast Reconstr Surg, 108, 938-948; discussion 949-951.

[129] Liu W., Sun X., Braut A., Mishina Y., Behringer R.R., Mina M., Martin J.F. (2005) Development, 132, 1453-1461.

[130] Juriloff D.M., Harris M.J., McMahon A.P., Carroll T.J., Lidral A.C. (2006) Birth Defects Res A Clin Mol Teratol, 76, 574579.

[131] Zhang J., Hagopian-Donaldson S., Serbedzija G., Elsemore J., Plehn-Dujowich D., McMahon A.P., Flavell R.A., Williams T. (1996) Nature, 381, 238-241.

[132] Qiu M., Bulfone A., Ghattas I., Meneses J.J., Christensen L., Sharpe P.T., Presley R., Pedersen R.A., Rubenstein J.L. (1997) Dev Biol, 185, 165-184.

[133] Peters H., Neubuser A., Kratochwil K., Balling R. (1998) Genes Dev, 12, 2735-2747. 
[134] Zhao Y., Guo Y.J., Tomac A.C., Taylor N.R., Grinberg A., Lee E.J., Huang S., Westphal H. (1999) Proc Natl Acad Sci U $S$ A, 96, 15002-15006.

[135] Szeto D.P., Rodriguez-Esteban C., Ryan A.K., O'Connell S.M., Liu F., Kioussi C., Gleiberman A.S., Izpisua-Belmonte J.C., Rosenfeld M.G. (1999) Genes Dev, 13, 484-494.

[136] Mills A.A., Zheng B., Wang X.J., Vogel H., Roop D.R., Bradley A. (1999) Nature, 398, 708-713.

[137] Jerome L.A., Papaioannou V.E. (2001) Nat Genet, 27, 286-291.
[138] Sock E., Rettig S.D., Enderich J., Bosl M.R., Tamm E.R., Wegner M. (2004) Mol Cell Biol, 24, 6635-6644.

[139] Bush J.O., Lan Y., Jiang R. (2004) Proc Natl Acad Sci U S A, 101, 7022-7027.

[140] Smith T.M., Wang X., Zhang W., Kulyk W., Nazarali A.J. (2009) Dev Dyn, 238, 23642373.

[141] Spiegelstein O., Mitchell L.E., Merriweather M.Y., Wicker N.J., Zhang Q., Lammer E.J., Finnell R.H. (2004) Dev Dyn, 231, 221-231.

[142] Culiat C.T., Stubbs L.J., Woychik R.P., Russell L.B., Johnson D.K., Rinchik E.M. (1995) Nat Genet, 11, 344-346. 
Table 1-Genes identified through syndromic clefts

\begin{tabular}{|l|l|l|l|l|}
\hline $\begin{array}{l}\text { S. } \\
\text { No: }\end{array}$ & \multicolumn{1}{|c|}{ Syndrome (OMIM) } & \multicolumn{1}{|c|}{ gene } & \multicolumn{1}{|c|}{$\begin{array}{c}\text { Cytogenetic } \\
\text { location }\end{array}$} & Reference \\
\hline 1 & Vander Woude syndrome (VWS) & IRF6 & $1 \mathrm{q} 32$-q41 & {$[21]$} \\
\hline 2 & Wolf-Hirschhorn syndrome (WHS) & MSX1 & 4 p16.3 & {$[25]$} \\
\hline 3 & Kallmann syndrome(KAL2) & FGFR1 & $8 p 11.2-p 11.1$ & {$[124]$} \\
\hline 4 & Cleft lip/palate ectodermal dysplasia syndrome & PVRL1 & $11 q 23.3$ & {$[125]$} \\
\hline 5 & $\begin{array}{l}\text { ectrodactyly-ectodermal dysplasia-cleft syndrome } \\
\text { (EEC) }\end{array}$ & TP63 & $3 q 28$ & {$[126]$} \\
\hline 6 & Cleft palate with ankyloglossia (CPX) & TBX22 & Xq21.1 & {$[37]$} \\
\hline 7 & Opitz syndrome, X-LINKED & MID1 & Xp22 & {$[39]$} \\
\hline 8 & Lymphedema-distichiasis syndrome & FOXC2 & $16 q 22-q 24$ & {$[40,41]$} \\
\hline 9 & Bamforth-Lazarus syndrome & FOXE1 & $9 q 22$ & {$[42]$} \\
\hline
\end{tabular}

Table 2- Genes and mouse models of cleft lip with or without cleft palate

\begin{tabular}{|l|l|l|l|}
\hline Gene/Strain & \multicolumn{1}{|c|}{ Gene function } & Mouse/Human gene location & Reference \\
\hline EDN1 & Signaling & Chr13/6p24.1 & {$[56]$} \\
\hline INHBA & Signaling & Chr13/7p15-p13 & {$[127]$} \\
\hline Tgfß3 & Signaling & Chr12/14q24 & {$[128]$} \\
\hline Bmp4 & Signaling & Chr 14/14q22-q23 & {$[129]$} \\
\hline Bmpr1a & Signaling & Chr 14/10q22 & {$[129]$} \\
\hline Wnt9b & Signaling & Chr 11/17q21 & {$[130]$} \\
\hline Msx1 & Transcription & Chr5/4p16.3-p16.1 & {$[50]$} \\
\hline Tcfap2a & Transcription & Chr 13/6p24 & {$[131]$} \\
\hline Dlx2 & Transcription & Chr2/2q32 & {$[132]$} \\
\hline Pax9 & Transcription & Chr12/14q12-q13 & {$[133]$} \\
\hline Lhx8 & Transcription & Chr3/1p31.1 & {$[134]$} \\
\hline Pitx1 & Transcription & Chr13/5q31 & {$[135]$} \\
\hline p63 & Transcription & Chr 16/3q28 & {$[136]$} \\
\hline Tbx1 & Transcription & Chr16/22q11.21 & {$[137]$} \\
\hline Sox11 & Transcription & Chr 12/2p25 & {$[138]$} \\
\hline Tbx10 & Transcription & Chr 19/11q13 & {$[139]$} \\
\hline Hoxa2 & Transcription & Chr6/7p15-p14 & {$[140]$} \\
\hline Folr1 & Folate transport & Chr 7/11q13 & {$[141]$} \\
\hline Gabr33 & y-aminobutyric acid receptor & Chr7/15q11.2-q12 & {$[142]$} \\
\hline GAD1 & y-aminobutyric acid-producing enzyme & Chr2/2q31 & \\
\hline & & & {$[60]$} \\
\hline
\end{tabular}



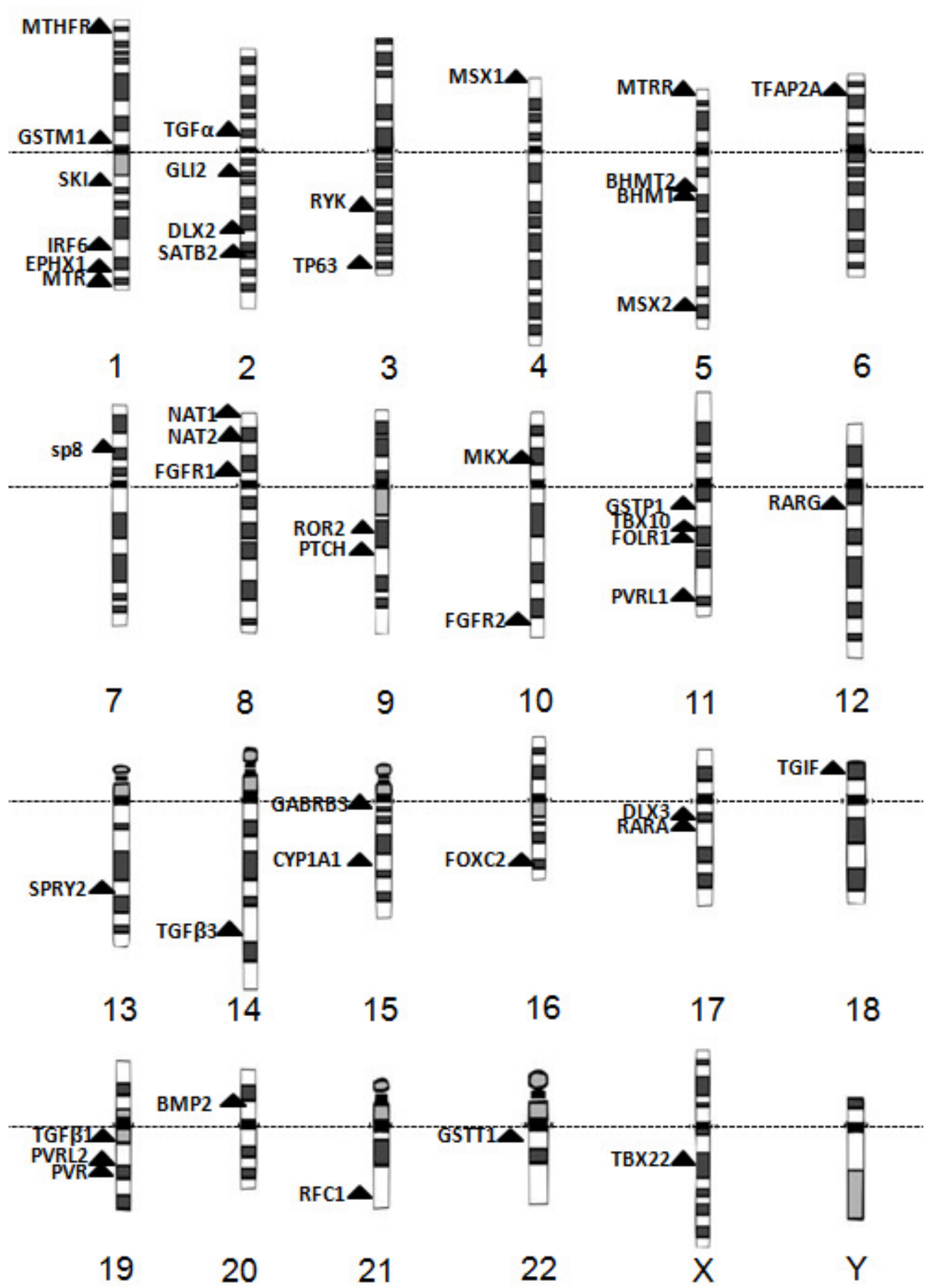

Fig. 1-Notable putative genes and chromosomal regions studied for non-syndromic cleft lip and palate using linkage and association strategies. 